\title{
Environmental hazard of Novoyavorivsk municipal landfill
}

\author{
Vasyl Popovych ${ }^{1, *}$, Kateryna Stepova ${ }^{1}$, and Oleksandr Prydatko ${ }^{1}$ \\ ${ }^{1}$ Lviv State University of Life Safety, 35 Kleparivska str., Lviv, Ukraine
}

\begin{abstract}
Novoyavorivsk is located near large sulfur deposits in a transborder with Poland. The existing sanitation system in Novoyavorivsk is imperfect. Municipal wastes are stored in cloughs, ravines, river valleys. This causes an environmental hazard, as polluted wastewater is discharged to the water bodies. The aim of the work is environmental hazard assessment of Novoyavorivsk landfill. The tasks of the research are as follows: determination of chlorides and sulfates content in the landfill edaphotopes; measurement of power of equivalent dose of photon radiation. Determination of chlorides and sulfates was carried out by quantitative and qualitative methods. The equivalent dose of photon radiation was measured by dosimeter by SOEKS USA, LLC. In different sites of the landfill chlorides and sulfates content differs. The most polluted areas are at the distance of $10 \mathrm{~m}$ and $50 \mathrm{~m}$ from the foot. At a distance of $100 \mathrm{~m}$ from the landfill, the concentration of chlorides reduces to $0.001 \%$ $(5 \mathrm{~cm})$ and $0.1 \%(10 \mathrm{~cm}$ and $20 \mathrm{~cm})$. High sulfate content is observed at 10 $\mathrm{m}$ from the foot of the landfill ( $1 \%$ in the $10 \mathrm{~cm}$ and $20 \mathrm{~cm}$ horizons). The power of the equivalent dose at a height of $10 \mathrm{~m}$ from the south side exceeds the pollution standard of $0.3 \mu \mathrm{Sv} / \mathrm{h}$ and equals $0.32 \mu \mathrm{Sv} / \mathrm{h}$.
\end{abstract}

\section{Introduction}

One of the most acute environmental problems of humanity is the management of municipal waste. The main ways of handling are recycling, combustion and accumulation at landfills.

The analysis of the morphological composition of municipal landfills in different countries showed that the highest amount of food waste and paper is accumulated, and the least is ash and wood. The Netherlands $(51.9 \%)$ and Ukraine $(45 \%)$ are the leaders in food waste. The highest amount of paper waste is accumulated in Canada (70\%), Sweden (44\%) and Japan (40.6\%), the least - in Spain (15\%) and Georgia (19\%). The amount of polymers (from 3 to $10 \%$ ), metals (from 2 to $9.5 \%$ ), textiles (from 2.4 to $5 \%$ ) and glass (from 6to $10 \%$ ) accumulated on the landfills is almost the same everywhere [1-3].

The accumulation of plastics, metal, glass, rechargeable batteries, electronic, medical, and chemical waste on landfills leads the release of toxic substances and compounds into the environment that may transform from one form to another for years causing the contamination.

\footnotetext{
*Corresponding author: popovich2007@ukr.net
} 
European countries began developing waste management models and eliminating existing landfills in the 70's of the last century. The main method of reducing the harmful effects of landfills was recultivation and vegetative reclamation. The technology of the engineering and technical complex of reclamation works included: recycling of accumulated waste, technical stage (strengthening of slopes, creation of geochemical barriers, installation of isolation screens), biological stage (artificial vegetative reclamation), environmental monitoring.

The regulatory documents in Ukraine that regulate the municipal landfills operation do not foresee the possibility of natural overgrowth of landfills [4]. The main rules for waste landfills designing include sowing of perennial grasses, tree planting, shrubbery only for the southern and northern regions of Ukraine, and without the necessary justification, the duration is determined by 4 years. Selection of vegetation species for forest or agricultural vegetative reclamation should be carried out not only in view of the regional location of landfills, but also taking into account the conditions of the edaphotope and microclimate, the morphological composition of municipal waste, the age of the landfill, combustion processes.

In total, there are 6,000 landfills in our country with a total area of almost 9 thousand hectares, $22 \%$ of which do not meet environmental safety standards. The largest number of such landfills is in Lugansk, Odesa, Kherson, Kharkiv, Kirovograd, Ternopil, Zakarpattia, Zaporozhye, Vinnytsia and Sumy regions. 94 of the 3,536 landfills requiring reclamation are actually reclaimed. The absence of a waste management system in settlements, as a rule in the private sector, led to about 23.7 thousand unauthorized dumps, covering an area of more than 750 hectares. About 50 million $\mathrm{m}^{3}$ or about 12 million tons of municipal waste are generated annually [5].

Novoyavorivsk was founded in 1965 as a working settlement "Yantarne" (from June 1969 - Novoyavorivske) near large sulfur deposits in a transboundary territory with Poland. The city has a well-developed infrastructure and a favorable economic location. Near the city there is the highway Lviv - Yavoriv (road M10 Lviv - Ivano-Frankivsk - Krakovets Krakow).

There is a ME "Novoyavorivskzhytlo" in the city. The purpose of this enterprise is the maintenance of the housing stock, provision of housing and communal services to the population and legal entities in the city, organizing of collection, sorting and removal of municipal and industrial waste, recycled materials, provision of services for urban improvement and gardening. The removal and storage of solid waste is carried out at the city landfill, which is located on the territory of the Zaluzhsky village council (15 km from Novoyavorivsk). At present time the construction of a landfill for the city of Novoyavorivsk is being carried out on the basis of the existing landfill on the territory of 5 hectares with a capacity of 148,632 thousand tons $\left(292,310\right.$ thousand $\left.\mathrm{m}^{3}\right)$, the lifetime of 10 years. It should be noted that on April 3, 2017 a fire has occurred on Novoyavorivsk dump. Garbage burned on an area of $3000 \mathrm{~m}^{2}$ [6].

In general, the existing structure of the sanitary cleaning system in Novoyavorivsk is imperfect and does not provide sufficient control over the sanitary state of the territories.

Municipal wastes, especially in rural settlements, are stored in natural relief formations cloughs, ravines, river valleys. This poses an environmental hazard, since wastewater saturated with pollutants enters the water bodies [7].

One of the first steps in developing of practical guidelines for determining the ways of landfill treatment and adaptation to environmental conditions is to determine their morphological composition. Identification of landfill content is necessary for vegetative reclamation planning, since the formation of humus and organic matter is a prerequisite for the development of phytocoenoses, which will improve the sanitary and environmental conditions. 
The technological imperfection of municipal landfills arrangement and operation causes the pollution of the air, surface and ground waters, creates a threat to deterioration of the environmental, sanitary and epidemiological conditions and health of the population, recreational resources degradation. The environmental situation gets complicated by the fact that waste management problems are not being solved for the long time, primarily because of the large volumes of their annual generation, low utilization and accumulation. The issue of keeping of municipal landfills in good condition is extremely relevant, especially in terms of multiplication of illegal dumpings.

The degree of pollution caused by landfills is influenced by the climate, relief and channel density. The environmental hazards are as follows:

- Chemical influence of releasing of hazardous substances with emissions of filtrate and biogas. Hazardous substances fall into soils and air, and from there in the reservoirs and plant foods that are grown near the landfills;

- Pyrogenic factor associated with the release of heat in the decomposition of waste and leads to self-heating of waste up to $+40 \ldots+70^{\circ} \mathrm{C}$. In case of insufficient heat transfer, there is self-ignition of waste causing the surface fires and inside smoldering with smoke release;

- The sanitary-epidemiological factor is the emergence a favorable environment for the development of pathogenic microorganisms in the body of a dump;

- Zoo-based factor is living of birds, reptiles, mammals on landfills;

- The social factor is that existing landfills create a risk and discomfort zone for people living or working near landfills, as well as changing the landscape, causing visual and aesthetic decline [8].

Negative phenomena in landfills are also alienation of fertile lands, mechanical impacts on soils, noise pollution during landfill operation and transportation of municipal waste, bad odor.

\section{Experimental procedures}

The aim of the work is environmental and technogenic hazard assessment of Novoyavorivsk municipal landfill. The tasks of the research are as follows:

- determination of chlorides and sulfates content in the landfill edaphotopes;

- measurement of power of equivalent dose of photon radiation.

Determination of chlorides and sulfates in soils was carried out by water extraction method, which is effective but labor-intensive (especially the determination of sulfates). For practical tasks, a quantitative and qualitative method is used that is much easier [9].

For the experiment the following reagents have been used: $\mathrm{HNO}_{3}$ solution $-10 \%$; $\mathrm{AgNO}_{3}$ solution $-0.1 \mathrm{~N} ; \mathrm{HCl}$ solution $-10 \%$ with a $10 \%$ solution of $\mathrm{BaCl}_{2} \cdot \mathrm{H}_{2} \mathrm{O}$.

The samples of waste were collected northeastward away from the landfill according to wind action approach. The surface of northeastern slope was chosen as there is no piling there and a new terrain has been formed. Method of samples collection was described by V.A. Kovda, B.G. Rozanov (1988). The composited sample was dried, grinded and riddled. $50 \mathrm{~g}$ were collected from the composited sample and placed in a flask then filled with distilled water in a ratio of 1:10. The contents were stirred for 3 minutes and filtered through a simple folded filter. If the filtrate formed takes a dye it was diluted with distilled water at a ratio of 1:10. The resulting filtrate was poured into 2 flasks.

Determination of the relative amount of chlorides and sulfates was carried out by gradation:

- the appearance of weak opalescence corresponds to the content of salts $0,001 \%$;

- the appearance of weak turbidity corresponds to a $0.01 \%$ salt content;

- the appearance of strong turbidity corresponds to the content of salts of $0,1 \%$; 
- The appearance of curdy precipitate for $\mathrm{Cl}$ and crystalline for $\mathrm{SO}_{4}$ corresponds to the amount of anion content of $1 \%$ and above [4].

The equivalent dose of photon radiation was measured by dosimeter by SOEKS USA, LLC. Measurement of the equivalent dose of photon radiation in a landfill was carried out at three levels - the foot, the middle and the top [10].

\section{Results and discussions}

In landfills vegetation obtains mineral nutrition from a newly formed substrate, characterized by salinity and depleted nutrient content.

If an element of mineral nutrition is absent or inadequate the plant undergoes irreversible physiological and biochemical changes [11-14]. The content of carbohydrates and the spare assimilants in the plant is influenced by chemical contaminants of the technogenic environment [15-21].

The salinity of man-made edaphotopes of landfills causes the migration of salts to the plants resulting in growth slowing and destruction. The content of $0.1-0.2 \%$ of watersoluble chloride salts and $>0.5 \%$ of sulfuric acid salts in the substrate is harmful to plants.

The violation of water availability under the influence of salts leads to a destruction of chloroplasts; disturbance of synthesis of chlorophyll-a and chlorophyll-b, changes in the bonds strength in the chlorophyll-protein-lipid complex plastids. Under the influence of salts as a result of the destruction of the chlorophyll-protein-lipid complex a complete discoloration of chlorophyll is observed (the change in the total color of the leaves, the appearance of pale areas - salt spots that increase over time).

The most effective measures of salty edaphotopes control are washing them with fresh water; desalinization by plants that accumulate significant amounts of salts (phytoremediation); salt-resistant plant species growing on salty edaphotopes; the use of salty edaphotopes for natural meadows and pastures [22, 23].

At Novoyavorivsk landfill the content of chlorides and sulfates is different depending on survey plot.

The most polluted areas of Novoyavorivsk landfill are located at a distance of $10 \mathrm{~m}$ and $50 \mathrm{~m}$ from the foot. At a distance of $100 \mathrm{~m}$ from the landfill, the concentration of chlorides is reduced to $0.001 \%(5 \mathrm{~cm})$ and $0.1 \%(10 \mathrm{~cm}$ and $20 \mathrm{~cm})$ (see fig. 1.)

High concentrations of sulfates in the Novoyavorivsk landfill are observed in substrates at a distance of $10 \mathrm{~m}$ from the foot of the landfill $(1 \%$ in the horizons $10 \mathrm{~cm}$ and $20 \mathrm{~cm})$ (Fig. 2).

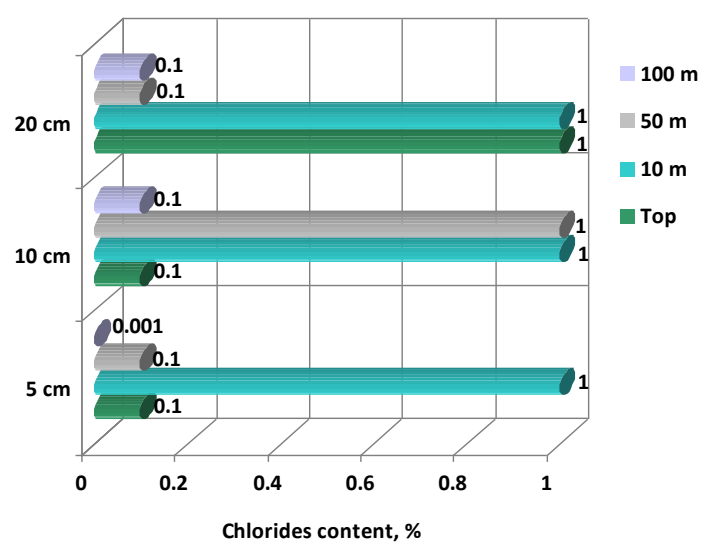

Fig. 1. The chlorides content in Novoyavorivsk landfill substrates. 


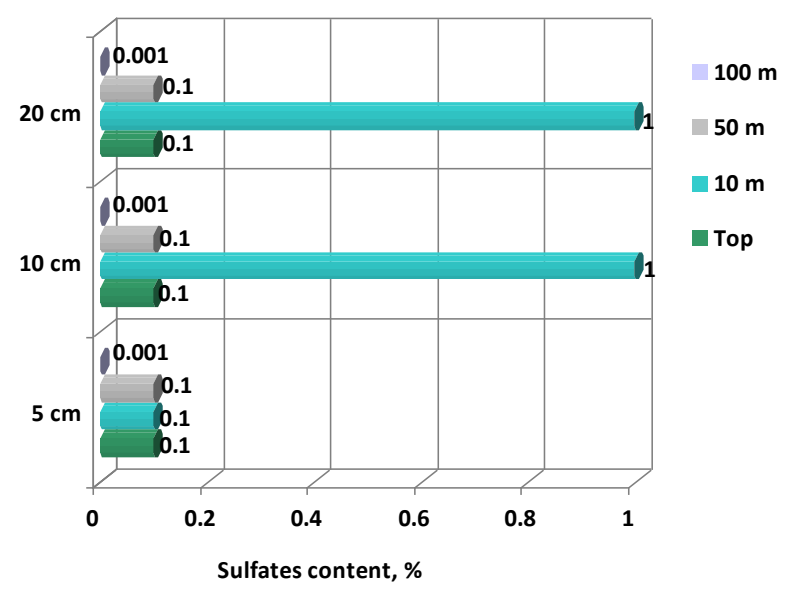

Fig. 2. The sulfates content in Novoyavorivsk landfill substrates.

The lowest sulfate content is observed at a distance of $100 \mathrm{~m}$ from the foot of the landfill and is equal to $0.001 \%$.

Ionizing radiation has high biological activity. Radionuclides tend to accumulate in soils and bottom deposits of reservoirs. They are easily adsorbed on the surfaces of plants and microorganisms, thus embedded in food chains. The radionuclides transportation in the ecosystem is associated with processes of erosion, fires, secondary transport by wind, aging and very slow destruction of radioactive particles. Living organisms are exposed to radionuclides mainly due to surface contact, inhalation and food [24-31].

The rehabilitation of radiation-tainted areas by vegetation is referred to in paper [32]. It is shown that during reforestation the future products due to the long-term forest maturing will comply with radiation standards. In the paper [33] an assessment of radionuclide pollution effect on the fluctuating asymmetry of Betula pendula Roth leaves was made. The presented results indicate that the transition of radionuclides to the vegetative mass is activated in the early stages of phytodemutation. The consequences of the Chernobyl accident in the flora of the surrounding area are described in the paper [34].

In paper [35] the investigation of the radiation situation in landfills and sludge tanks is described. It is established that the power of the exposure dose on the slag dam is $1.5-3$ times lower than the background values. The author suggests using slag for construction needs. In a landfill, the power of the exposure dose exceeds the background value.

From this perspective, the investigation of background radiation of devastated landscapes is a relevant task, in particular - the landfills which are under-investigated. The dependence of the radiation background on natural phytomelioration processes was determined at the Novoyavorivsk municipal waste landfill. According to the plan of research, the following tasks were foreseen:

- to measure the radiation background of the dumps, namely, the power of an equivalent dose of photon radiation and the density of beta particles flow;

- compare indices of different sites of the landfill (with and without grass cover);

- to establish the dependence of the radiation background on natural vegetative reclamation processes.

The research was conducted under the following weather conditions: the ambient temperature $-+18{ }^{\circ} \mathrm{C}$, air relative humidity $-33 \%$, wind speed $-1 \mathrm{~m} / \mathrm{s}$, atmospheric air pressure - 102,5 $\mathrm{kPa}$ abs., without atmospherical condensation. According to the research program, the measurement of the equivalent dose of photon radiation and the density of the 
beta-particles flux at a distance of $500 \mathrm{~m}, 400 \mathrm{~m}, 300 \mathrm{~m}, 200 \mathrm{~m}, 100 \mathrm{~m}$ from the landfill, and at the foot, at the middle and top from all sides were carried out. The similar measurements were carried out in Ivan Franko Park in Lviv being considered as the background values consisting of:

- the power of an equivalent dose of photon radiation $\left({ }^{137} \mathrm{Cs}\right)-0,07 \mu \mathrm{Sv} / \mathrm{h}$;

- the density of the $\beta$-flow $\left({ }^{90} \mathrm{Sr}+{ }^{90} \mathrm{Y}\right)-0,001$ particles $/\left(\mathrm{cm}^{2} \cdot \min \right)$.

According to the "Norms of Radiation Safety of Ukraine" (NRSU-97) the level of 0.30 $\mu \mathrm{Sv} / \mathrm{h}$ is considered to be the maximum allowable level of gamma background (which most influences on biological organisms).

An analysis of the results of the equivalent dose of photon radiation showed that it exceeds the background value $(0.15 \mu \mathrm{Sv} / \mathrm{h})$ on some areas of the landfill. The maximum allowable level of gamma background (which most influences on biological organisms) is considered to be $0.30 \mu \mathrm{Sv} / \mathrm{h}$ [36].

At an average level (10 $\mathrm{m}$ from the foot of the landfill), the power of photon radiation is much larger than in other areas of the landfill (Fig. 3).

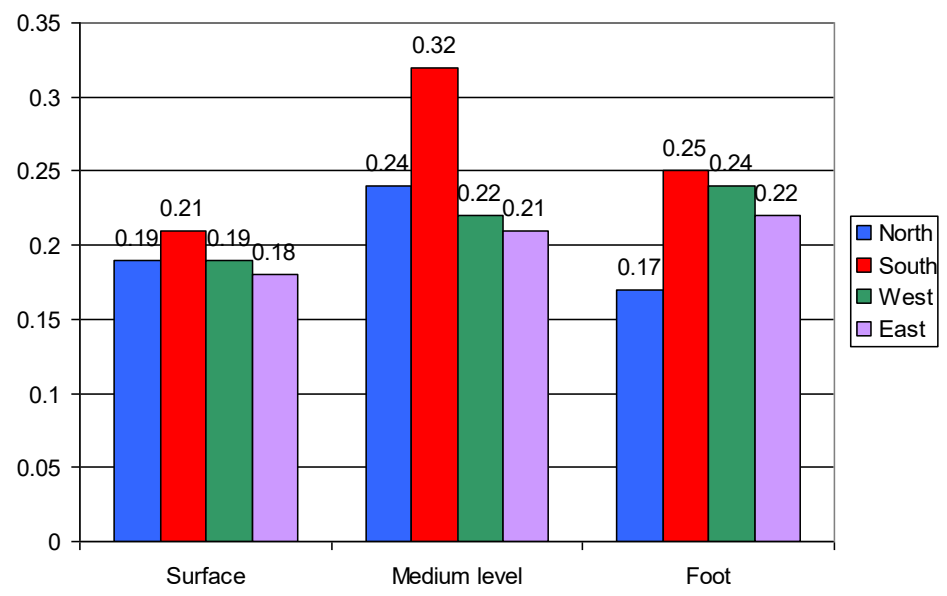

Fig. 3. The equivalent dose of photon radiation in the landfill $(\mu \mathrm{Sv} / \mathrm{h})$.

\section{Conclusions}

The excess of chloride and sulphate content in edaphotopes leads to irreversible changes in the all biological objects. Chlorides and sulfates may result in destruction of the chlorophyll-protein-lipid complex that is a complete discoloration of chlorophyll (the change in the total color of the leaves, the appearance of pale areas - salt spots increasing over time), plants die and deformed external characteristics.

As a result of photon radiation measurements at the Novoyavorivsk landfill it has been established that the power of the equivalent dose at individual sites (at a height of $10 \mathrm{~m}$ from the south side) exceeds the allowable norm of $0.3 \mu \mathrm{Sv} / \mathrm{h}$ and equals $0.32 \mu \mathrm{Sv} / \mathrm{h}$ (southern slope).

\section{References}

1. V. Ulyanov, Ecol. Bull. 1 (1997)

2. I.V. Makhota, Ecol. \& Nat. Res. Manag. 11 (2008) 
3. Zh.M. Zhapparova, Izuchenie soderzhaniya tyazhelyh metallov v pochvogruntah $v$ rayone raspolozheniya poligona tverdyh bytovyh othodov, (NIO, Ecol., 2008)

4. State Building Acts of Ukraine B.2.4-2-2005 (2005)

5. A.M. Pryshchepa, O.A. Brezhytska, Bull. of Nat. Univ. of Wat. \& Nat. Res. Manag. 3(39) (2007)

6. UAINFO. (2017, 03 April 2017). UAINFO - Internet Freedom Organization. Available from: https://uainfo.org/blognews/1491224774-na-yavorivshchini-spalahnulamasshtabna-pozhezha-na-smittezvalishchi.html

7. V. Popovych, Biol. News. of MSPU 1 (2016)

8. L. Hrybanova, Tver. Byt. Oth. 7 (2006)

9. Metodika issledovaniya svoystv tverdyh otbrosov (Pamfilov Ac. of Com. Serv. 1970)

10. Radiation Safety Standards of Ukraine (RSSU-97)

11. I. Bukharina, Phisiologiya rasteniy (Izhevsk, 2009)

12. P. Hnativ, Lisiv. Ac. N. Ukr. Nauk. Pr. 1 (2002)

13. Promyshlennaya botanika (Kiev, N.D. 1980)

14. Fitotoksichnost' organicheskikh i neorganicheskikh zagryazniteley (Kiev, N.D. 1986)

15. Yu. Alekseyev, Tyazhelyye metally v pochvakh i rasteniyakh (Agroprom. 1987)

16. V. Bezsonova, Ukr. Bot. J. 49 \#2 (1992)

17. I. Voloshin, L. Matviichuk, Vis. of Lviv Univ.: Geogr. 34 (2007)

18. Zh. Huralschuk, Fitotoksychnist' vazhkykh metaliv ta stiykist' roslyn do yikh diyi (Kiev: Logos, 2006)

19. V.V. Karabyn, A.S. Voytsikhovs'ka, V.D. Pohrebennyk, Nauk. Pr. DonNTU. Ser. Hirn.-heol. 16/206, (2012)

20. A. Raguotis, Ekol. (Vilnius), 3 (1999)

21. T.M. Roane, I.L. Pepper, R.M. Miller, Bioremediation: principles and applications (UK: Cambridge Univ. Press, 1996)

22. V.F. Selevtsev, Primeneniye agrokhimicheskikh analizov $v$ planirovanii sistemy udobreniya (Yekaterinburg: Ural. GSKHA, 1996)

23. A.A. Shakhov, Solestoykost' rasteniy (AN SSSR. 1956)

24. V.V. Demchuk, O.V. Martyniuk, O.V. Fedorenko, L.V. Troyan, Envir. Health 2 (2010)

25. I.V. Matveyeva, Nauk. Pr. Petro Mohyla Chornomor. Derzh. Univ.: Tekhnoh. Bezp. 203/191 (2012)

26. V.I. Prymenko, B.T. Kanunnikov, O.P. Zhyzhchenko, V.K. Pastukhov, Herald of NAU $1(2005)$

27. INSAG7. Chernobyl accident: addition to INSAG1. Report of the International Nuclear Safety Advisory Group. (Vienna: IAEA, 1993).

28. Report of the United Nations Scientific Committee on the Effects of Atomic Radiation to the General Assembly. Annex J. Exposures and effects of the Chernobyl accident. (2000)

29. Report of the United Nations Scientific Committee on the Effects of Atomic Radiation to the General Assembly. Exposures to the public from manmade sources of radiation. Annex C. (2000).

30. Report of the United Nations Scientific Committee on the Effects of Atomic Radiation to the General Assembly (2000) 
31. B. Salbu, O. C. Lind, Radiopr. Suppl. 1., Vol. 40, № 1 (2005)

32. V.P. Protsak, V.O. Kashparov, A.F. Hoychuk etc. Sc. Bull. of Ukr. St. For. Univ. of Ukr. "Ecol. and Econ. Teach.": sci.-tech. works. 14.5 (2004)

33. D.D. Hanzha, Lisiv. i ahrol. 113 (2008)

34. I.M. Hudkov, Lyud. ta dovk. Probl. Neoekol. 3-4 (2011)

35. D.A. Haponov, Vyyavleniye $i$ otsenka geofizicheskimi metodami lokal'nogo tekhnogennogo zagryazneniya geologicheskoy sredy $v$ mestakh razmeshcheniya otkhodov proizvodstva i potrebleniya (Rostov-on-Don, 2011)

36. I.I. Nikberg, Ioniziruyushchaya radiatsiya i zdorov'ye cheloveka (Kiev, Zdor., 1989) 